Prof. J. P. O'Donnell, University College, Dublin; Honorary Secretary/Treasurer, Mr. J. Kelleher, Shamrock Fertilizers, Wicklow; Assistant Honorary Secretary, Mr. R. K. Sinnott, Du Pont (U.K.) Ltd., Londonderry; Mr. E. V. Casburn, Seaweed Ltd., Galway; Dr. F. L. Kafka, Du Pont (U.K.) Ltd., Londonderry; Mr. I. MeCallum, Irish Refining Co. Ltd., Whitegate, Co. Cork; Mr. P. H. Whitaker, Chemstrand Ltd., Coleraine, Co. Derry; Mr. W. A. D. Windham, Arthur Guinness Son and Co. Ltd., Dublin. The objects of the Committee are " $(a)$ to promote an interest in chemical engineering in Ireland, including interest in the schools; (b) to bring chemical engineers together for discussions on matters of technical interest; (c) to provide a representative opinion of chemical onginoors in Ireland". Further information can bo obtained from: Mr. J. Kelleher, "Fernhurst", Hillsido Road, Greystones, Co. Wicklow, or the General Secretary, the Institution of Chemical Engincors, 16 Belgrave Square, London, S.W.1.

\section{Science and the Public Mind}

A memorandum by W. Schramm, Science and the Public Mind, based on various studies in the Unitod States of public knowledge of seience and scientists, supports the view that knowlodge of science is widely, but not deeply, distributed in the United States (American Association for the Advancement of Science. Miscellaneous Publication No. 62-3: Science and the Public Mind: A Memorandum for $E$. G. Sherburne, Jr., from Wilbur Schramm. Pp. 20. Washington, D.C.: American Association for the Advancement of Scienco, 1962). There are still large areas of ignorance and an individual's education is the chief predictor of his knowledge of science, followed by use of mass media; after loaving school, mass media supply most of the increment in knowledge. Whoro such information is sought depends largely on the topic and on the characteristics of tho individual. The more personalized and/or sensational is a seientific article the larger is its audience, and mass media tend to use theso techniques in roporting scionce and to select material that can be so treated. It is to be regretted that they do not apply to matorial for entertainment the same standards of scientific accuracy that they apply to advice and reporting. Public attitudes towards science and scientists are generally favourable, although not very accurately informed. The public is interested in getting more scientific information, but the acquisition of new scientific information does not nocessarily result in a logical chain of belief, attitude and behaviour. Besides noting somo negative indicators as to what information on science should be provided for the public, Mr. Schrarnm suggests ways in which scientists themselves can help, for example, by paying closer attontion to school curricula in science and to the lovol of science teaching, contributing to the training of science writers, facilitating the dissemination of information about their work and encouraging the study of the processes by which seientific knowledge is conveyed and applied.

\section{Incomes Policy and the Professional Employee in Britain}

IN a pamphlet, Incomes Policy and the Professional Employee, issued by the National Union of Teachers, Mr. M. Shanks, reviewing eritically the Govornment's attompt to operate an incomes policy, suggests that the National Incomes Commission should be made a representative body (Pp. 15. London: National Union of Teachers, 1962). He argues that the National Economic Devolopment Council is the most logical agent to formulate an incomes policy, and that under such a policy the salaries of professional employees would be determined by assossing tho nation's noed for such services and a formula designed to keep these salaries in a propor relation to industrial wages. This relation needs first of all to be agrood, and Mr. Shanks rofors to the boliof that in Wostorn domocracies there is a built-in distortion in favour of the private sector as against the public sector.

\section{The British Hat and Allied Feltmakers Research Association}

The fifteenth annual roport of the Director of Research of the British Hat and Allied Feltmakers Researeh Association, covering the yoar ended August 1962, refers to a survey of the storage cellars of membors which established tho general pattern of bactorial infoction and showed a highly significant relation between the dogree of infection and tho season of delivery (Pp. 22. Droylsden, Manchester: British Hat and Allied Feltmakers Research Association, 1962). 'This programme limited progress on the carrotting of fur, but the Blankenburg and Zahn method of assessing the felting ability of wool was examined. Work continued on dyeing felt with acid milling dyes for fully-planked fur folt and half-planked wool felt and a. study was made of the incidence of gas-fume fading of dyed fur and wool felts, whilo the problom of hat sizes has been further investigated and the geometrical properties of hatters' ovals have been summarized in a technical report. Factors likely to influence the development of static electricity in the forming machines were examined, and anomalous results of tho coefficients of friction of felt havo boon attributed to contamination of the contact sorvices with grease, while the programme comparing other possible matorials with folt as padding in protectivo headgear was completed. A list of publications is appended.

\section{Trade Associations and Professional Bodies of the United Kingdom}

The directory Trade Associations and Professional Bodies of the United Kingdom, compiled by Patricia Millard, is designed to provide a ready means of finding the address and telephone numbor of any nationally important trado, professional or technical association in the United Kingdom and of identifying the associations with any specific field of activity. With few exceptions, only national organizations are included, but trade unions, livery companies and chambers of commerce are excluded. The directory is in two parts: an alphabetical directory and a classified index with cross-hoadings (Pp. viii +128 . London: C.B.D. Research, Ltd., 24 Holborn Viaduct, 1962. 30s.).

\section{A Bibliography of Personnel Management}

A BIBLIOGRAPHY recently published by the Instituto of Personnol Management replaces that published by the Institute in 1950 and its subsequent supplements (Personnel Management: a Bibliography. Pp. 39. London: Institute of Personnel Management, 1962. 7s.6d.). The books have been selected as helpful to the personnel manager who wishes to broaden his knowledge of the background of his job, and those included in the Institute's oxamination book list for students are marked. Tho books are arrangod in eleven sections, the last doaling with sourees of information, and the selection appears to be well-balanced and representativo within the broad headings.

\section{Dogs and Stilbœestrol}

Dogs (18 fomale, 4 male) wore given subcutaneous injections of diethylstilbostrol at intervals of 4-6 weoks by Dr. Anno G. Jabara, of the Dopartment of Pathology. University of Melbourno, and developed alopecia after 11 months (Austral. J. Exp. Biol., 40; 1962). All aroas except the head and distal parts of the legs were affocted and tho denudod skin became dry, scaly and excoriatod. Microscopic changos wore observed in all oloments of tho skin, and the hair follicles woro atrophic. The hair grew again 3-7 months after injections woro stopped, and at nocropsy $11-14.5$ months later the skin was histologically 